\title{
Effects of hippotherapy on children with cerebral palsy: systematic review and meta-analysis
}

\author{
Kwon-Hoi Kim $\left.{ }^{\mathrm{a}(}\right)$, Suk-Min Lee ${ }^{\mathrm{b}(1)}$ \\ ${ }^{a}$ Team of Physical Therapy, Catholic University of Korea, Uijeongbu ST. Mary's Hospital, Uijeongbu, Republic of Korea \\ bepartment of Physical Therapy, College of Health and Welfare, Sahmyook University, Seoul, Republic of Korea
}

\begin{abstract}
Objective: The most important goal of hippotherapy is to improve function, gait, and balance. The purpose of this study was to in-
\end{abstract} vestigate the effects of hippotherapy on function, gait, and balance of children with cerebral palsy (CP).

Design: A systematic review and meta-analysis.

Methods: We've searched the PubMed, EMBASE, and Cochrane Library CENTRAL databases for English experimental studies published up until September 2018. To analyze the effects of hippotherapy on the function, gait, and balance of children with cerebral palsy, the systematic review and meta-analysis were performed on Patient/Participants/Population Problem, Intervention, Comparison, Outcome with Timing, Setting Study Design. Papers retrieved from the database were removed from the literature management database. Methodological quality evaluation was evaluated using Cochrane's risk of bias. Data was analyzed using the Revman 5.3 program of the Cochrane library.

Results: In this study, we found that the effect size of hippotherapy, denoted as d, was -3.82 , and that hippotherapy had the most effect on gait, but no statistical significant difference was observed. We also found no significant difference in function and balance after hippotherapy. It was found from the funnel plot that there was no publication bias as the plot was symmetrically distributed around the dotted line.

Conclusions: There are many unclear studies and a lack of randomized controlled trials (RCTs) in this research area. More RCTs on the effects of hippotherapy on children with CP should be conducted in the future.

Key Words: Balance, Cerebral palsy, Function, Gait, Hippotherapy

\section{Introduction}

Cerebral palsy (CP) is a disorder characterized by impairments in autonomic movement and posture for non-progressive disease or damage to the brain that has developed into a disease of the central nervous system [1]. The prevalence of $\mathrm{CP}$ worldwide is estimated to be between 2 and 3 per 1,000 live births [2]. CP affects not only the motor system, but it often is connected to neurocognitive, sensory, and sensitive disorders [3]. Children with CP experience difficulties with controlling the body's position in space, performing anticipatory adjustments for executing functional activities, and reacting to unexpected perturbations of balance [4]. To improve the quality of life of people with $\mathrm{CP}$, it is necessary to apply a very comprehensive and multidisciplinary approach with an emphasis on appropriate rehabilitation [5]. Interventions must focus on all areas of the body structures and function, level of activity, and participation in order to have a positive influence on the quality of life of the child [6].

Over the years, several treatment methods have been developed (e.g., neurodevelopmental treatment, the Vojta method, conductive education, sensory integrative therapy) that differ in their specific treatment strategies, but aim at leading children with CP toward the greatest degree of independence possible [7]. Many traditional physical therapy inter-

Received: 25 November, 2019 Revised: 3 March, 2020 Accepted: 11 March, 2020

Corresponding author: Suk-Min Lee (ORCID https://orcid.org/0000-0002-0602-956X)

Department of Physical Therapy, College of Health and Welfare, Sahmyook University, 815 Hwarang-ro, Nowon-gu, Seoul 01795, Republic of Korea Tel: 82-2-3399-1632 Fax: 82-2-3399-1639 E-mail: leesm@syu.ac.kr

(a) This is an Open-Access article distributed under the terms of the Creative Commons Attribution Non-Commercial License (http://creativecommons.org/licenses/ by-nc/4.0) which permits unrestricted non-commercial use, distribution, and reproduction in any medium, provided the original work is properly cited.

Copyright $(\odot 2020$ Korean Academy of Physical Therapy Rehabilitation Science 
vention for children with CP focus on impairments within the child at the domain of body function and structure [8]. However, physical activity provides many benefits to these individuals, including the improvement of functional abilities, including balance, and delaying the progression of some disorders [9]. Hippotherapy is used as a strategic treatment method for children with motor disabilities using horses as part of integrated therapy. This method entails teaching horse riding skills to individuals with disabilities. Hippotherapy is used to treat horses to health professionals such as physiotherapists and occupational therapists [10]. Therapeutic strategies of horse movement are considered to reach functional outcomes [11].

In horseback riding, movements of the horse affect the rider such that the rider experiences various physical changes. A horse's rhythmic movement necessitates delicate collaborative movements of the rider's neck, torso, and limb muscles [12]. Due to some forms of walking is similar between horses and humans, horseback riding results in creating threedimensional movements in the rider [13]. The American Equestrian Association reported that hippotherapy improves muscle tone, balance, postural control, cooperation, and motor development. Therefore, the most important goal of hippotherapy is to improve balance, posture, function, and mobility [14].

Hippotherapy has demonstrated short term benefits of inducing symmetry of muscles in the trunk and hip and reducing asymmetry of the adductor muscles. Moreover, it was recognized as inducing improved vestibular and proprioceptive stimulation and increased body awareness [15]. Recently, randomized controlled trial (RCT) studies using hippotherapy have been increasing. There were no RCT studies on hippotherapy in PubMed provided by the US National Library of Medicine before 1997, but since then, there has been a steady increase every year, with 43 RCT studies on hippotherapy in 2018.

The broader the scope of the meta-analysis, the more comprehensive it becomes; however, there is a wide range of outcomes of a particular disease, and a narrow scope makes the discussion of the various effects of hippotherapy difficult [16]. In an earlier meta-analysis of hippotherapy, the effect of hippotherapy on all diseases was investigated. This metaanalysis showed no significant effects on gross motor function measure (GMFM) and pediatric balance scale (PBS) on CP [9]. However, A meta-analysis of the effects of hippotherapy on children with $\mathrm{CP}$ in regards to some of its specific effects was also conducted. This meta-analysis showed sig- nificant effects on balance [14]. Previous results have been different.

Meta-analyses of hippotherapy have been conducted, but this is the first meta-analysis on hippotherapy for children with CP. In addition, we've included studies on hippotherapy for children with $\mathrm{CP}$ to investigate the effects of the therapeutic intervention and to determine its effect size on function, gait, and balance.

\section{Methods}

\section{Protocol}

The method used in this study is presented in a protocol registered with PROSPERO (PROSPERO registration number: CRD42018108721). We received approval for this study from the Institutional Review Board (IRB NO. 2-7001793AB-N-012018082HR). This review was conducted by the checklist of the Preferred Reporting Items for Systematic Reviews and Meta-analysis. The search strategy of the review was performed by two researchers. To analyze the effects of hippotherapy on function, gait, and balance of children with $\mathrm{CP}$, a systematic review and meta-analysis were performed on Patient/Participants/Population Problem, Intervention, Comparison, Outcome with Timing, Setting Study Design.

\section{Identification and selection of studies}

The inclusion criteria for this review were the following: (1) participants were children with CP; (2) intervention used in the study was hippotherapy; (3) outcome measurements included function, gait, and balance. Studies were excluded if: (1) the study was written in languages other than English; (2) the study was not published as the full reports; (3) any other types of study design other than RCTs; (4) studies not providing data on baseline score or end-point outcome.

We searched the core electronic databases, namely PubMed, EMBASE, and Cochrane Library CENTRAL. The search terms included words for children with CP (Patient: P) and words for hippotherapy (Intervention: I). After checking the medical subject headings (MeSH), which are control words from PubMed, we selected $2 \mathrm{MeSH}$ words ("equine-assist therapy" OR “cerebral palsy"). The retrieval equations were constructed by connecting control words, which include relevant central keywords identified in the abstract, with "OR." In EMBASE, which is a European electronic database, the control word was checked in EMTREE using the same method as for PubMed. The search was conducted on 
September 2, 2018, using the following keywords: ('cerebral palsy'/exp OR 'brain palsy' OR 'brain paralysis' OR 'central palsy' OR 'central paralysis' OR 'cerebral palsy' OR 'cerebral paralysis' OR ‘cerebral paresis' OR ‘encephalopathia infantilis' OR 'palsy, cerebral' OR 'spastic diplegia') AND ('hippotherapy'/exp OR 'equine assisted therapy' OR 'equine-assisted therapy' OR 'hippotherapy' OR 'horseback riding therapy'). In the Cochrane Library CENTRAL, a search was made using the MeSH words from PubMed.

\section{Data extraction}

We only considered papers published in English from the date of first data entry into the electronic database to September 2018. Papers retrieved from the databases were removed from the literature management database (Endnote X8; Clarivate Analytics, Philadelphia, PA, USA). Duplicate articles were eliminated. The title and abstract of the papers were confirmed, and the original texts of the selected publications were then reviewed according to the inclusion criteria. The exclusion criteria were described, and the final selection of materials was obtained (Figure 1).

\section{Quality assessment}

Evaluation in the RCTs was performed using the Cochrane's Risk of Bias tool developed by The Cochrane Bias Method

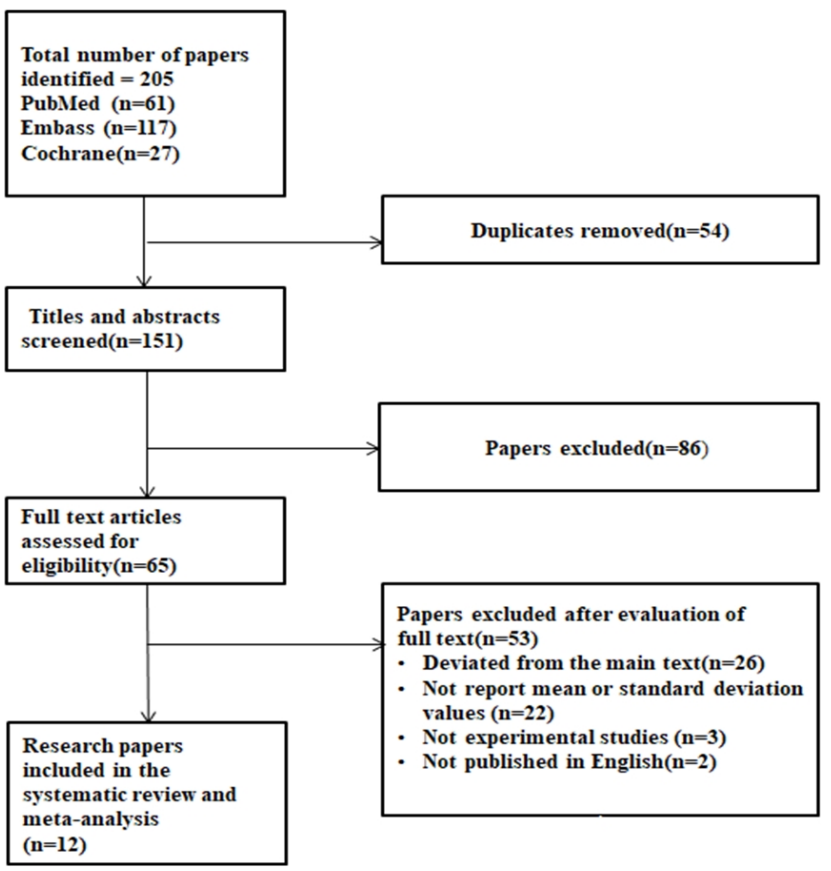

Figure 1. Preferred Reporting Items for Systematic Reviews and Meta-analysis flow diagram.
Group. The quality of the papers was evaluated on the basis of random sequence generation, allocation concealment, blinding of participants and personnel, blinding of outcome assessment, incomplete outcome data, selective reporting, and other forms of bias. Non-RCTs and single-group clinical trials were used in quality assessment as Risk of Bias Assessment Tools for Non-randomized Studies. For RoB and RoBANS, the bias risk was divided into "high," "low," and "uncertain." A "low" bias risk indicates a low probability of bias, "high" bias risk indicates a high probability of bias; and "uncertain" indicates risk that is difficult to determine [17]. The RevMan 5.3 program (The Cochrane Collaboration, Copenhagen, Denmark) was used for the evaluation and explanation of results.

\section{Data analysis}

In the meta-analyses, the effect size of the intervention was calculated using the RevMan 5.3 program of the Cochrane Library. Meta-analysis was performed when the same outcome variables were analyzed or when there were pre- and post-quantitative values for outcome variables. Meta-analysis was also performed when more than 2 studies were conducted for each outcome variable. The mean differences and standard deviations before and after the intervention in the selected study articles were used for analysis. To assess the effect estimate of the selected RCTs, the mean and standard deviation values were pooled to obtain the mean difference and $95 \%$ confidence intervals (CI). The effect size was calculated using a random-effects model that resets the weights considering heterogeneity among studies. The homogeneity of study subjects was confirmed using Cochrane's chi-square test and the $\mathrm{I}^{2}$ test. The $\mathrm{I}^{2}$ value is $0 \%$ when there is no heterogeneity, $30 \%$ to $60 \%$ for moderate heterogeneity, and $75 \%$ for severe heterogeneity [17]. Publication bias of the included research papers was tested using a funnel plot [18]. Publication bias was evaluated with a visual inspection of the funnel plot for asymmetry and subsequently with Egger's test when: 1. Asymmetry of funnel plot was observed; and 2. When 10 studies were included in a metaanalysis (http://handbook.cochrane.org). Publication bias was not assessed as there were less than 10 studies included for meta-analysis [19].

\section{Results}

\section{Study selection process}

A total of 205 articles were retrieved from overseas data- 
bases using the titles and abstracts of the research papers in PubMed, EMBASE, and Cochrane Library CENTRAL. Using the literature management database (Endnote X8), 54 duplicate articles were identified and excluded, leaving 151 of the original 205 for selection. Of the 151 articles, 86 did not meet the inclusion criteria, leaving 65 original study articles for selection. Of these 65 articles, 26 deviated from the main text, 22 did not report the mean or standard deviation values, three were non-experimental studies, and two were not published in English. Twelve studies met all inclusion criteria and constituted the final selection of studies (Figure 1).

\section{Methodological quality}

The RoB tool developed by the Cochrane group was used for the eight RCT papers and the RoBANS tool for the four single-group clinical trial papers (Figure 2). One of the eight RCT papers selected as final articles was considered to have a high degree of bias $(+)$, which was described in detail in the other seven articles. Allocation concealment was described in 4 papers, and blinding of participants and personnel was considered to be low $(-)$ in five papers. Blinding of the evaluator was described in five papers and was considered to be low ( - ). With regard to incomplete outcome data, one paper was considered as extremely weak and six were considered to be mildly weak. Selective outcome reporting was described in all studies. A manual for intervention was available in some cases and the intervention provider was considered an expert. Regarding the methodological quality evaluation of four single-group clinical trials, the selection of a target group was not reported in 1 article and blinding of the evaluator was not reported in 3 papers. Results were not presented in 1 article (Figure 2).

\section{Effects of hippotherapy}

In this study, the characteristics of 12 intervention studies on hippotherapy for children with CP were analyzed. The number of participants was 2 or less $(16.6 \%), 5(41.7 \%)$ from 11 to 20 participants, and $5(41.7 \%)$ from 21 or more participants. The number and percentage of children with CP who were $\leq 6$ years, $7-8$ years, and $\geq 9$ years were 2 $(16.6 \%), 5(41.7 \%)$, and $3(25.1 \%)$, respectively. The age of 2 children (16.6\%) was unclear. The types of CP were spastic, diplegic, bilateral spastic, and total in $6(50 \%), 1(8.3 \%)$, $2(16.6 \%)$, and $3(25.1 \%)$ children, respectively. The interventions used in the included studies were hippotherapy, hippotherapy with conventional therapy, and hippotherapy with active trunk extension in $6(50 \%), 5(41.7 \%)$, and 1 (8.3\%) studies, respectively. Hippotherapy was administered at a mean duration of 38.75 minutes/session 1.63 times/week for 9.62 weeks (Tables 1, 2) [27,28,30-33,35-40]. In this study, meta-analysis of the effects of hippotherapy on the function, gait, and balance of children with CP was performed in 9 of the 12 studies included in this study.
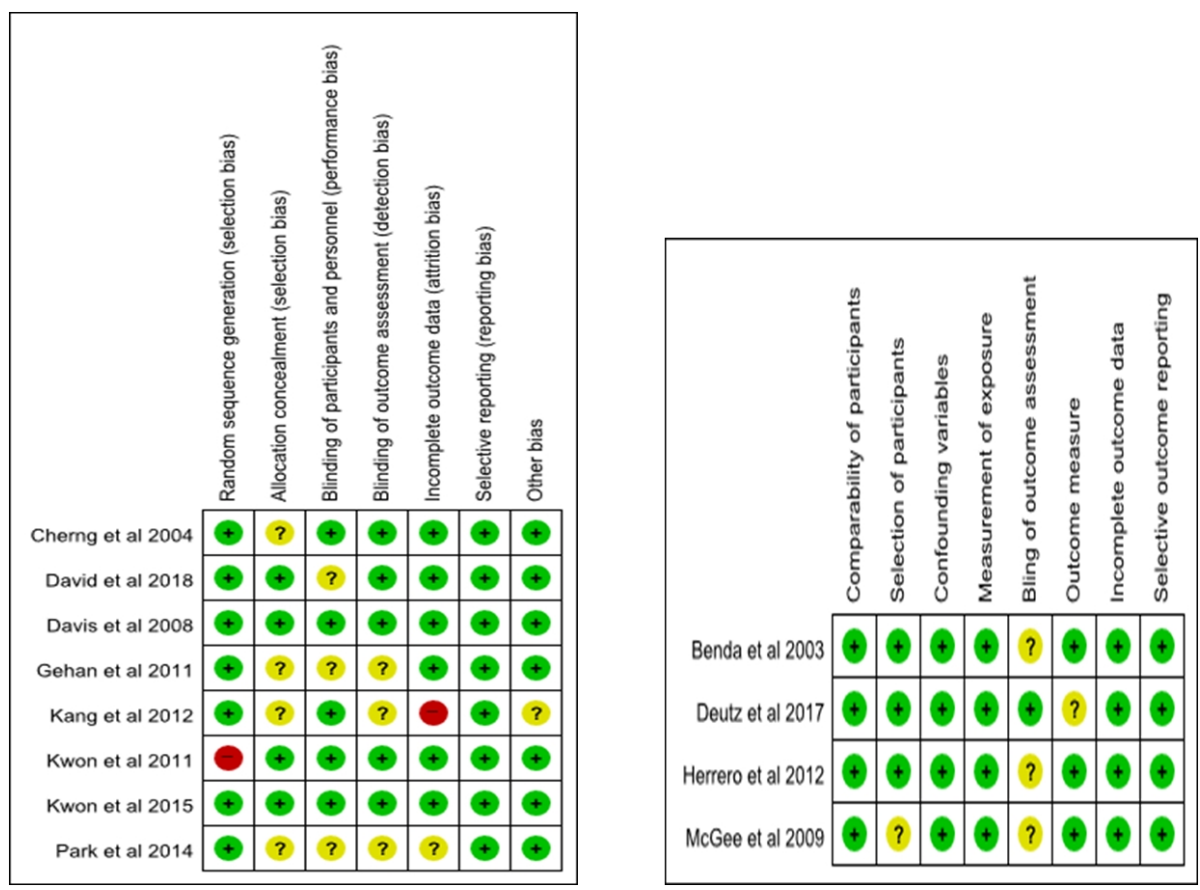

Figure 2. Methodological evaluation. 
Table 1. Descriptive summary of included studie

$(\mathrm{N}=12)$

\begin{tabular}{|c|c|c|c|c|c|}
\hline Study & Sample characteristics & Interventions & Control groups & Outcomes (scales) & Results \\
\hline $\begin{array}{l}\text { Lucena- } \\
\text { Antón } \\
\text { et al. [35] }\end{array}$ & $\begin{array}{l}\text { RCT of the effects of a } \\
\text { hippotherapy intervention } \\
\text { protocol on hip adductor } \\
\text { spasticity in children with } \\
\text { spastic CP of GMFCS levels } \\
\text { IV-V ( } \mathrm{n}=22) \text { and in the } \\
\text { control group }(\mathrm{n}=22)\end{array}$ & $\begin{array}{l}\text { Type: hippotherapy in addition } \\
\text { to conventional treatment } \\
\text { Format (setting): hospital } \\
\text { Providers: physical therapist } \\
\text { Session: } 45 \text { min } 1 \text { time/week } \\
\text { for } 12 \mathrm{wk}\end{array}$ & $\begin{array}{l}\text { Conventional } \\
\text { group }\end{array}$ & 1) MAS & 1) Decreased MAS \\
\hline $\begin{array}{l}\text { El-Meniaw } \\
\text { y and } \\
\text { Thabet } \\
{[36]}\end{array}$ & $\begin{array}{l}\text { RCT of an exercise program } \\
\text { for children with spastic } \\
\text { diplegia with emphasis on } \\
\text { posture correction }(n=15) \text { and } \\
\text { of hippotherapy in addition to } \\
\text { the exercise program }(n=15) \\
\text { in children of GMFCS levels } \\
\text { I-II }\end{array}$ & $\begin{array}{l}\text { Type: hippotherapy in addition } \\
\text { to conventional treatment } \\
\text { Format (setting): clinic } \\
\text { Providers: physical therapist } \\
\text { Session: } 1 \text { hour } 3 \text { times/week } \\
\text { for } 3 \text { mo }\end{array}$ & $\begin{array}{l}\text { Conventional } \\
\text { group }\end{array}$ & 1) Back geometry & $\begin{array}{l}\text { 1) Improvement in } \\
\text { back geometry }\end{array}$ \\
\hline $\begin{array}{l}\text { Kwon } \\
\text { et al. [37] }\end{array}$ & $\begin{array}{l}\text { RCT of hippotherapy effects on } \\
\text { temporospatial parameters } \\
\text { and pelvic and hip kinematics } \\
\text { of gait in children with } \\
\text { bilateral spastic CP of } \\
\text { GMFCS levels I-II }(n=16) \\
\text { and in the conventional } \\
\text { treatment group }(n=16)\end{array}$ & $\begin{array}{l}\text { Type: hippotherapy in addition } \\
\text { to conventional treatment } \\
\text { Format (setting): riding ground } \\
\text { Providers: physical therapist } \\
\text { Session: } 30 \text { minutes/session } 2 \\
\text { days/week for } 8 \mathrm{wk}\end{array}$ & $\begin{array}{l}\text { Conventional } \\
\text { group }\end{array}$ & $\begin{array}{l}\text { 1) Temporospatial } \\
\text { parameters } \\
\text { 2) Pelvic and hip } \\
\text { kinematics } \\
\text { 3) PBS }\end{array}$ & $\begin{array}{l}\text { 1) Improved } \\
\text { temporospatial } \\
\text { parameters } \\
\text { 2) Improved pelvic } \\
\text { and hip } \\
\text { kinematics } \\
\text { 3) Increased GFMF } \\
\text { 4) Increased PBS }\end{array}$ \\
\hline $\begin{array}{l}\text { Kwon } \\
\text { et al. [30] }\end{array}$ & $\begin{array}{l}\text { RCT of hippotherapy effects on } \\
\text { the gross motor function of } \\
\text { children with CP of GMFCS } \\
\text { levels I-IV }(n=45) \text { and in the } \\
\text { control group }(n=46)\end{array}$ & $\begin{array}{l}\text { Type: hippotherapy in addition } \\
\text { to conventional treatment } \\
\text { Format (setting): therapy center } \\
\text { Providers: physical therapist } \\
\text { Session: } 30 \text { minutes/session, } \\
\text { twice weekly for } 8 \\
\text { consecutive wk }\end{array}$ & $\begin{array}{l}\text { Conventional } \\
\text { group }\end{array}$ & $\begin{array}{l}\text { 1) GMFM } \\
\text { 2) PBS }\end{array}$ & $\begin{array}{l}\text { 1) Increased } \\
\text { GMFM } \\
\text { 2) Increased PBS }\end{array}$ \\
\hline $\begin{array}{l}\text { Davis } \\
\text { et al. [27] }\end{array}$ & $\begin{array}{l}\text { RCT of the impact of } \\
\text { therapeutic horse riding on } \\
\text { children with CP of GMFCS } \\
\text { levels I-III }(n=35) \text { and in the } \\
\text { control group }(n=37)\end{array}$ & $\begin{array}{l}\text { Type: hippotherapy } \\
\text { Format (setting): individual } \\
\text { (hospital) } \\
\text { Providers: hippotherapist } \\
\text { Session: } 10 \text {-wk study period }\end{array}$ & Control group & $\begin{array}{l}\text { 1) GMFM } \\
\text { 2) CHQ } \\
\text { 3) QoL (CP } \\
\text { QoL-child, } \\
\text { KIDSCREEN) }\end{array}$ & $\begin{array}{l}\text { 1) No significant } \\
\text { changes } \\
\text { 2) No significant } \\
\text { changes } \\
\text { 3) No significant } \\
\text { changes }\end{array}$ \\
\hline $\begin{array}{l}\text { Park } \\
\text { et al. [38] }\end{array}$ & $\begin{array}{l}\text { RCT of hippotherapy effects on } \\
\text { gross motor function and } \\
\text { functional performance of } \\
\text { children with CP of GMFCS } \\
\text { levels I-IV }(n=28) \text { and of the } \\
\text { control group }(n=21)\end{array}$ & $\begin{array}{l}\text { Type: hippotherapy } \\
\text { Format (setting): community } \\
\text { Providers: occupational } \\
\text { therapist } \\
\text { Session: } 45 \text { minutes/session } \\
\text { twice a week for } 8 \mathrm{wk}\end{array}$ & Control group & $\begin{array}{l}\text { 1) GMFM } \\
\text { 2) PEDI }\end{array}$ & $\begin{array}{l}\text { 1) Increased } \\
\text { GMFM } \\
\text { 2) Increased PEDI }\end{array}$ \\
\hline $\begin{array}{l}\text { Herrero } \\
\text { et al. [33] }\end{array}$ & $\begin{array}{l}\text { A stratified single-blind RCT } \\
\text { of the effects of a simulator } \\
\text { on children with CP of } \\
\text { GMFCS levels I-V }(n=19) \text { or } \\
\text { on the control group }(n=19)\end{array}$ & $\begin{array}{l}\text { Type: hippotherapy with active } \\
\text { extension of the trunk } \\
\text { Format (setting): school } \\
\text { Providers: not reported } \\
\text { Session: } 15 \text { minutes/session } \\
\text { once a week for } 10 \mathrm{wk} \\
\text { Follow-up: } 3 \text { mo post-training }\end{array}$ & $\begin{array}{l}\text { Non-simulator } \\
\text { hippotherapy } \\
\text { group }\end{array}$ & $\begin{array}{l}\text { 1) GMFM } \\
\text { 2) Sitting } \\
\text { Assessment } \\
\text { Scale }\end{array}$ & $\begin{array}{l}\text { 1) Improved } \\
\text { GMFM } \\
\text { 2) Improved sitting } \\
\text { balance }\end{array}$ \\
\hline
\end{tabular}

\section{Effect on function}

The GMFM-66 was assessed in 4 studies; no heterogeneity was found between the studies $\left(\mathrm{I}^{2}=0 \%\right)$, and the ef- fect size was -2.24 (95\% confidence interval $[\mathrm{CI}]:-5.72$, 1.24). The effect size on function was not statistically significant $(p=0.21)$. A total of 3 articles from studies that assessed GMFM-88 were selected for meta-analysis. There 
Table 1. Continued

\begin{tabular}{|c|c|c|c|c|c|}
\hline Study & Sample characteristics & Interventions & Control groups & Outcomes (scales) & Results \\
\hline $\begin{array}{l}\text { Cherng } \\
\text { et al. }[31]\end{array}$ & $\begin{array}{l}\text { RCT of the effectiveness of } \\
\text { therapeutic horseback riding } \\
\text { in children with spastic CP } \\
(n=9) \text { and in the control group } \\
(n=5)\end{array}$ & $\begin{array}{l}\text { Type: therapeutic horseback } \\
\text { riding in addition to regular } \\
\text { treatment } \\
\text { Format (setting): training center } \\
\text { Providers: pediatric physical } \\
\text { therapist } \\
\text { Session: } 40 \text { minutes/session } 2 \\
\text { sessions/week for } 16 \mathrm{wk}\end{array}$ & Control group & $\begin{array}{l}\text { 1) GMFM } \\
\text { 2) MAS }\end{array}$ & $\begin{array}{l}\text { 1) Improved } \\
\text { GMFM } \\
\text { 2) No significant } \\
\text { changes in } \\
\text { muscle tone }\end{array}$ \\
\hline $\begin{array}{l}\text { Kang } \\
\text { et al. [32] }\end{array}$ & $\begin{array}{l}\text { RCT of hippotherapy effects on } \\
\text { the sitting balance of children } \\
\text { with severe CP }(\mathrm{n}=15), \text { a } \\
\text { physical therapy group } \\
(\mathrm{n}=15) \text {, and a control group } \\
(\mathrm{n}=15)\end{array}$ & $\begin{array}{l}\text { Type: hippotherapy } \\
\text { Format (setting): individual } \\
\text { (hospital) } \\
\text { Providers: physical therapist } \\
\text { Session: } 45 \text { minutes/session } \\
\text { twice a week for } 8 \mathrm{wk}\end{array}$ & $\begin{array}{l}\text { Physical therapy } \\
\text { group and no } \\
\text { treatment } \\
\text { group }\end{array}$ & $\begin{array}{l}\text { 1) Left/right } \\
\text { pathway } \\
\text { 2) Total pathway } \\
\text { 3) Left/right } \\
\text { velocity } \\
\text { 4) Total velocity }\end{array}$ & $\begin{array}{l}\text { 1) Decreased } \\
\text { left/right } \\
\text { pathway } \\
\text { 2) Decreased total } \\
\text { pathway } \\
\text { 3) Decreased } \\
\text { left/right velocity } \\
\text { 4) Decreased total } \\
\text { velocity }\end{array}$ \\
\hline $\begin{array}{l}\text { Benda } \\
\text { et al. [39] }\end{array}$ & $\begin{array}{l}\text { Single pre-post test of } \\
\text { hippotherapy effects on } \\
\text { muscle activity in children } \\
\text { with spastic CP }(n=15)\end{array}$ & $\begin{array}{l}\text { Type: hippotherapy } \\
\text { Format (setting): community } \\
\text { Providers: physical therapist } \\
\text { Session: } 8 \text { min }\end{array}$ & None & 1) Muscle activity & $\begin{array}{l}\text { 1) Improved } \\
\text { symmetry in } \\
\text { muscle activity }\end{array}$ \\
\hline $\begin{array}{l}\text { McGee } \\
\text { et al. [28] }\end{array}$ & $\begin{array}{l}\text { Single pre-post test of } \\
\text { hippotherapy effects on gait } \\
\text { parameters in children with } \\
\text { spastic CP of GMFCS levels } \\
\text { I-III }(n=9)\end{array}$ & $\begin{array}{l}\text { Type: hippotherapy } \\
\text { Format (setting): university } \\
\text { Providers: pediatric physical } \\
\text { therapist } \\
\text { Session: } 1 \text { session lasting } \\
30-45 \text { min }\end{array}$ & None & $\begin{array}{l}\text { 1) Temporal and } \\
\text { spatial gait } \\
\text { parameters }\end{array}$ & $\begin{array}{l}\text { 1) Increased } \\
\text { temporal and } \\
\text { spatial gait } \\
\text { parameters }\end{array}$ \\
\hline $\begin{array}{l}\text { Deutz } \\
\text { et al. [40] }\end{array}$ & $\begin{array}{l}\text { A randomized open-label } \\
\text { crossover study of hippotherapy } \\
\text { effects on children with } \\
\text { bilateral CP of GMFCS levels } \\
\text { II-IV in early }(\mathrm{n}=35) \text { and late } \\
(\mathrm{n}=38) \text { treatment groups }\end{array}$ & $\begin{array}{l}\text { Type: hippotherapy } \\
\text { Format (setting): hospital } \\
\text { (center) } \\
\text { Providers: physical therapist } \\
\text { Session: } 1-2 \text { sessions/week for } \\
\text { 16-20 wk }\end{array}$ & None & $\begin{array}{l}\text { 1) GMFM } \\
\text { 2) CHQ } \\
\text { 3) KIDSCREEN }\end{array}$ & $\begin{array}{l}\text { 1) Improved } \\
\text { GMFM } \\
\text { 2) Improved CHQ } \\
\text { 3) improved } \\
\text { KIDSCREEN } \\
\text { scores }\end{array}$ \\
\hline
\end{tabular}

RCT: randomized controlled trial, CP: cerebral palsy, GMFCS: gross motor function classification system, MAS: modified aschworth scale, GMFM: gross motor function measure, PBS: pediatric balance scale, QoL: quality of life, PEDI: pediatric evaluation of disability inventory, CHQ: child health questionnaire.

was no heterogeneity between the studies $\left(\mathrm{I}^{2}=0 \%\right)$, and the effect size was $-1.73(95 \%$ CI: $-5.89,2.43)$. The effect size on function was not statistically significant $(p=0.41)$. Three research papers reported on GMFM-B, and no heterogeneity was found between the studies $\left(\mathrm{I}^{2}=0 \%\right)$. The effect size in these studies was -0.62 . (95\% CI: $-4.55,3.30)$, but no statistical significance was observed $(p=0.76)$ (Figure 3 ).

\section{Effect on gait}

Four studies assessed GMFM-E (gait-related measurements) and were selected for the meta-analysis. There was no heterogeneity between the studies $\left(\mathrm{I}^{2}=0 \%\right)$, and the effect size was calculated using the random-effects model. The effect size in these studies was $-3.82(95 \% \mathrm{CI}$ : $-12.71,5.06)$.
However, no statistical significance was observed $(p=0.40)$ (Figure 3).

\section{Effect on balance}

Two studies that reported PBS values were selected in a meta-analysis of balance. There was no heterogeneity between the studies $\left(\mathrm{I}^{2}=0 \%\right)$. The effect size was calculated using the random-effects model. The effect size in these studies was -3.60 (95\% CI: $-9.07,1.87)$ but no statistically significant difference was observed between the studies ( $p=$ 0.20) (Figure 3).

\section{Bias test and reliability test for calculated effect size}

It was found from the funnel plot that there was no pub- 
Table 2. Descriptive summary of included studies $\quad(\mathrm{N}=12)$

\begin{tabular}{|c|c|}
\hline Characteristics & Value \\
\hline \multicolumn{2}{|l|}{ General } \\
\hline \multicolumn{2}{|l|}{ Year } \\
\hline$\leq 2010$ & $4(30.0)$ \\
\hline 2011-2013 & $4(30.0)$ \\
\hline 2014-2016 & $2(20.0)$ \\
\hline$\geq 2017$ & $2(20.0)$ \\
\hline \multicolumn{2}{|l|}{ Country } \\
\hline Korea & $4(30.0)$ \\
\hline USA & $2(20.0)$ \\
\hline Spain & $2(20.0)$ \\
\hline $\begin{array}{l}\text { Other countries (Egypt, Australia, } \\
\text { Thailand, Germany) }\end{array}$ & $4(30.0)$ \\
\hline \multicolumn{2}{|l|}{ Study design } \\
\hline $\mathrm{RCT}$ & $8(70.0)$ \\
\hline Single-group clinical trial & $4(30.0)$ \\
\hline \multicolumn{2}{|l|}{ Participants } \\
\hline \multicolumn{2}{|l|}{ Sample size: clinical trial } \\
\hline$\leq 10$ & $2(16.6)$ \\
\hline $11-20$ & $5(41.7)$ \\
\hline$\geq 21$ & $5(41.7)$ \\
\hline \multicolumn{2}{|l|}{ Age (y) } \\
\hline$\leq 6$ & $2(16.6)$ \\
\hline $7-8$ & $5(41.7)$ \\
\hline$\geq 9$ & $3(25.1)$ \\
\hline Unclear & $2(16.6)$ \\
\hline \multicolumn{2}{|l|}{ CP type } \\
\hline Spastic & $6(50.0)$ \\
\hline Diplegia & $1(8.3)$ \\
\hline Bilateral spastic & $2(16.6)$ \\
\hline Total & $3(25.1)$ \\
\hline \multicolumn{2}{|l|}{ GMFCS level } \\
\hline I-II & $2(16.6)$ \\
\hline I-III & $2(16.6)$ \\
\hline I-IV & $2(16.6)$ \\
\hline $\mathrm{I}-\mathrm{V}$ & $1(8.3)$ \\
\hline II-IV & $1(8.3)$ \\
\hline IV-V & $1(8.3)$ \\
\hline Unclear & $3(25.1)$ \\
\hline \multicolumn{2}{|l|}{ Interventions } \\
\hline \multicolumn{2}{|l|}{ Type } \\
\hline Hippotherapy & $6(50.0)$ \\
\hline Hippotherapy + conventional therapy & $5(41.7)$ \\
\hline $\begin{array}{l}\text { Hippotherapy }+ \text { active trunk } \\
\text { extensions }\end{array}$ & $1(8.3)$ \\
\hline \multicolumn{2}{|l|}{ Setting } \\
\hline Home/community & $2(16.6)$ \\
\hline Hospital/clinic & $7(58.5)$ \\
\hline Riding ground & $1(8.3)$ \\
\hline School & $2(16.6)$ \\
\hline \multicolumn{2}{|l|}{ Providers } \\
\hline Physical therapist & $7(58.5)$ \\
\hline Occupational therapist & $1(8.3)$ \\
\hline Pediatric physical therapist & $2(16.6)$ \\
\hline Hippotherapist & $1(8.3)$ \\
\hline Self/Unclear & $1(8.3)$ \\
\hline
\end{tabular}

Table 2. Continued

\begin{tabular}{cc}
\hline Characteristics & Value \\
\hline Duration (mean) & 38.75 minutes/session \\
Hippotherapy & 1.63 times/week for 9.62 wk \\
Outcomes and measurements & \\
Physical activity & $4(30.0)$ \\
GMFM-66 & $3(25.1)$ \\
GMFM-88 & $2(16.6)$ \\
GMFM dimension A & $3(25.1)$ \\
GMFM dimension B & $2(16.6)$ \\
GMFM dimension C & $2(16.6)$ \\
GMFM dimension D & $4(30.0)$ \\
GMFM dimension E & $2(16.6)$ \\
Gait (walking) & \\
Temporospatial parameters & $2(16.6)$ \\
Balance & $1(8.3)$ \\
Pediatric balance scale & \\
Sitting assessment scale & $2(16.6)$ \\
QoL & $2(16.6)$ \\
KIDSCREEN & \\
Spasticity & \\
MAS &
\end{tabular}

Values are presented as mean (SD) or $\mathrm{n}(\%)$.

CP: cerebral palsy, GMFCS: gross motor function classification system, QoL: quality of life, RCT: randomized controlled trial, GMFM: gross motor function measure, MAS: modified aschworth scale.

lication bias as the plot was symmetrically distributed around the dotted line (Figure 4). For objective verification, Egger's regression test [20], which is a statistical analysis method for publication errors, was used to examine the relationship between the effect size and the standard error. In this study, less than 10 studies were included in the meta-analysis, so no Egger's regression test was conducted.

\section{Discussion}

The aim of this study was to investigate the effects of hippotherapy on function, gait, and balance of children with CP. The most important goal of hippotherapy is to improve function, gait, balance. In this study, we aimed to determine systematically and objectively the therapeutic intervention effect of hippotherapy on children with CP through metaanalysis. We included 12 trials from a total of 205 and found evidence of the effects of hippotherapy on function, gait, and balance of children with CP. Of the 12 studies included, 9 were meta-analyses, and 3 were systematic reviews. Metaanalyses can provide information for establishing a rational and valid basis for clinical decision-making, avoiding unnecessary repetitive research, and finding comprehensive 


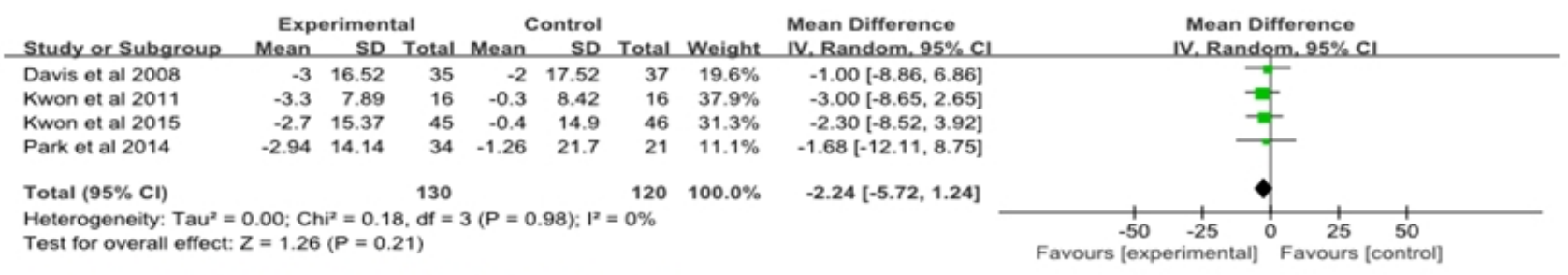

3A. The effect of hippotherapy on function (GMFM-66)

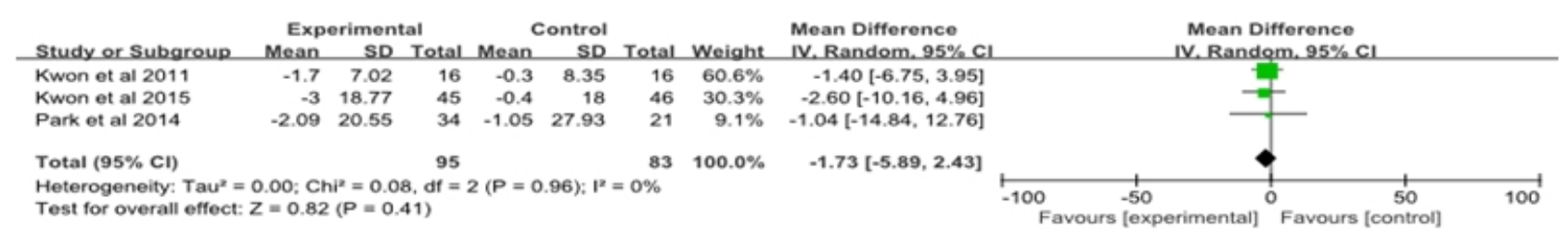

3B. The effect of hippotherapy on function (GMFM-88)

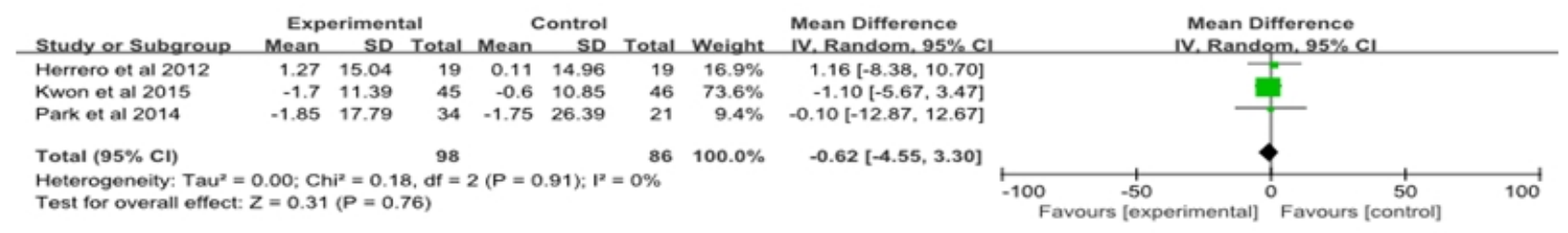

3C. The effect of hippotherapy on function (GMFM-B)

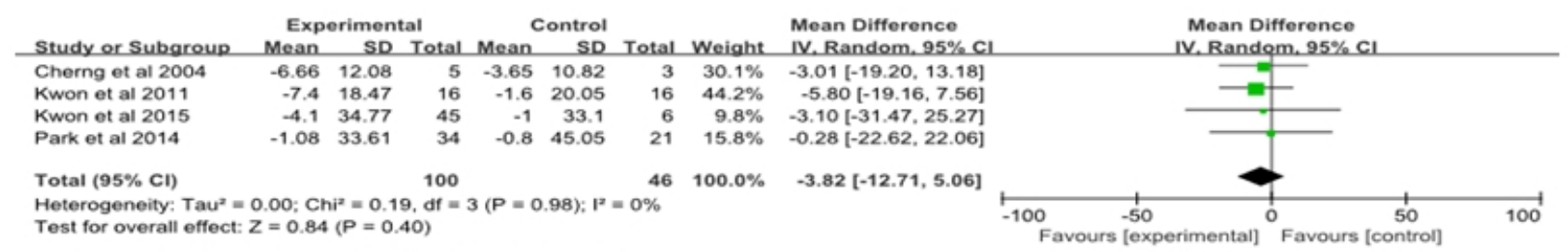

3D. The effect of hippotherapy on gait (GMFM-E)

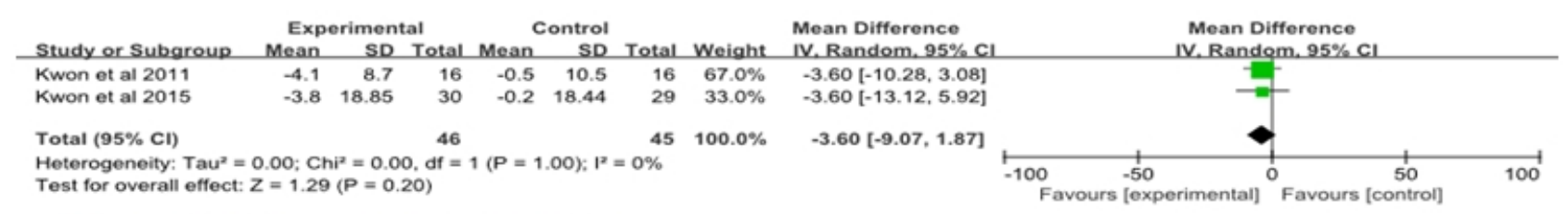

3E. The effect of hippotherapy on bal ance (PBS)

Figure 3. Forest plots of the effects of hippotherapy. GMFM: gross motor function measure, PBS: pediatric balance scale.

results that can be generalized by integrating and analyzing individual research results systematically [21]. In the 9 metaanalyses on the therapeutic intervention of children with $\mathrm{CP}$, the important outcome variables were function, balance, and gait. Function relates to physical activity, is evaluated in terms of GMFM, and is the most researched outcome variable. A recent meta-analysis on the effects of hippo- therapy reported statistically insignificant results for GMFM [9]. Most of the studies showed a trend toward a beneficial effect of hippotherapy on balance and gross motor function. About the function in this study, GMFM 66 analyzed four studies, GMGM 88 analyzed four studies, and GMFM-B analyzed three studies. The effect of the hippotherapy was evaluated by $\mathrm{d}=-2.24, p>0.05$ for the GMFM $66, \mathrm{~d}=-1.73$, 


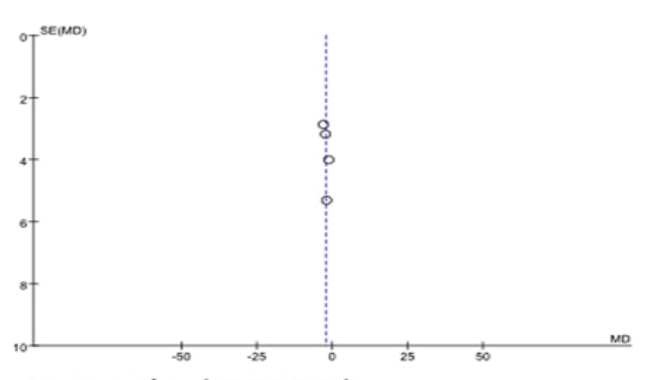

4A. Function (GMFM-66)

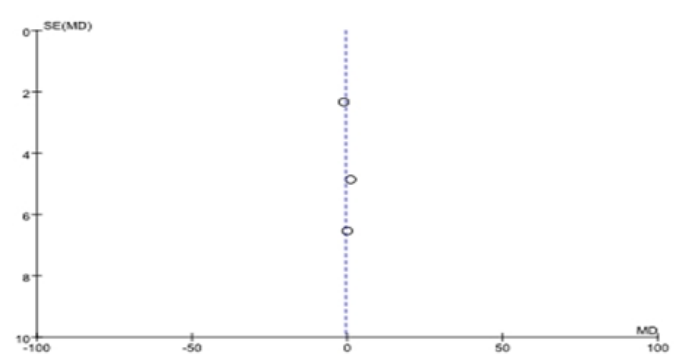

4C. Function (GMFM-B)

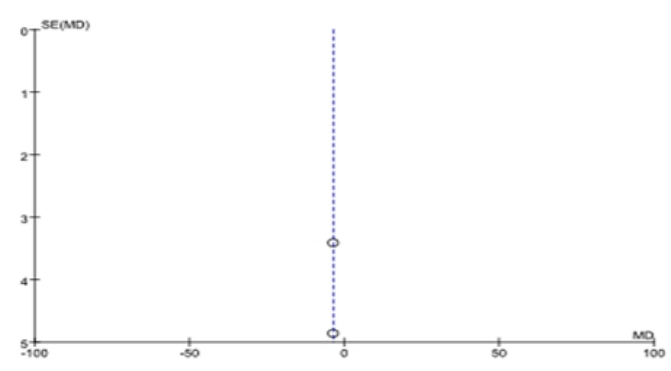

4E. Balance (PBS)

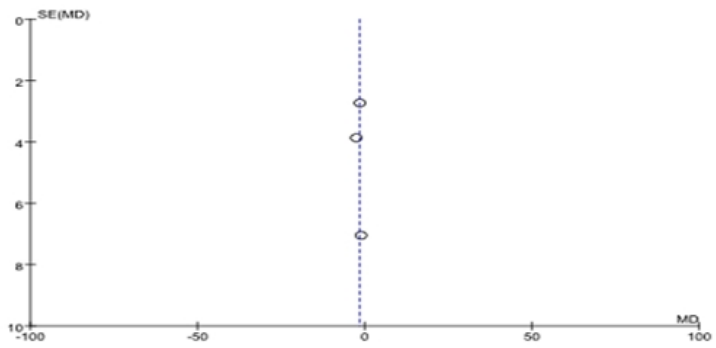

4B. Function (GMFM-88)

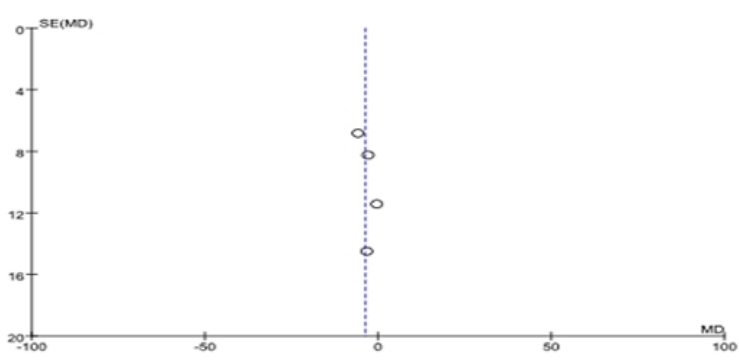

4D. Gait (GMFM-E)

Figure 4. Funnel plot of standard error by standardized mean difference. GMFM: gross motor function measure, PBS: pediatric balance scale.

$p>0.05$ for the GMFM $88, \mathrm{~d}=-0.62$ and $p>0.05$ for the GMFM-B, respectively, and the results were not significant. In the previous study, no significant heterogeneity was observed for participants with $\mathrm{CP}$, the $\mathrm{Q}$ statistic was equivalent to $1.11(p=0.77)$, and the I 2 was found equal to $0 \%$, indicating that there was no heterogeneity between the studies. The results of the meta-analysis showed the following $p>$ 0.05 results and showed the same results as the results of this study [9].

According to a recent study, hippotherapy for $\mathrm{CP}$ is elective and geared toward improving function [22]. Hippotherapy is an effective treatment option for improving function and balance of children with CP [23]. Children with neuromuscular disorders can benefit from hippotherapy if they have a problem with balance [24]. In addition, the evaluation of gait and balance in children with $\mathrm{CP}$ who have undergone hippotherapy is a good way to assess the long-term effects of hippotherapy [25]. This study report shows that the statistical results were different in each study. In the study by Casady and Nichols-Larsen [26], 10 children with CP aged 2.3-6.8 years showed improved results when GMFM was evaluated following 10 weeks of a weekly rehabilitation regimen. In contrast, Davis et al. [27] reported that GMFM scores were not significantly different after hippotherapy.

The meta-analysis performed in our study showed statistically insignificant differences in function after hippotherapy. GMFM-E was used to evaluate gait, and 4 meta-analyses were conducted. An improvement in GMFM-E represents improvement in gait [28]. The study by McGibbon et al. [29] reported that an average of 9.6 children with $\mathrm{CP}$ who completed the rehabilitation regimen twice a week for 8 weeks had improved GMFM-E values. In our study, the effect size on gait was high $(\mathrm{d}=-3.82)$ but not statistically significant. PBS was used to evaluate balance, and the results of 2 stud- 
ies were meta-analyzed. Increase in PBS scores is an effect of hippotherapy in children with CP [30]. An earlier metaanalysis reported no statistically significant differences in PBS [31]. However, a study reported significant results in balance [32]. Herrero et al. [33] reported that the sitting balance ability of 19 children with CP improved after hippotherapy. However, the study did not report any statistically significant differences. Previous study report shows that the statistical results were different in each study. It is necessary to present data in a more objective and scientific way to measure hippotherapy.

In this study, the methodological quality of 12 studies was evaluated. The RoB tool developed by the Cochrane group was used for the 8 RCT papers. One of the 8 RCT articles was not randomized. In the randomized study, the difference between the experimental and control groups was purely due to the effect of the intervention. Systematic reviews and meta-analyses of RCTs are considered strong bases for rating systems of evidence-based guidelines. Therefore, it is necessary to establish a randomized control design to improve the quality of future studies [34-40].

The results of this study showed that the maximum effect size was $\mathrm{d}=-3.82$, and the balance effect size was $\mathrm{d}=-3.60$. Next, $\mathrm{d}=-2.24$ measured by GMFM 66 when applied to the function, $\mathrm{d}=-1.73$ and GMFM-B $\mathrm{d}=-0.62$ when measured by GMFM 88 . The homogeneity among the studies ensures that the magnitude of the effect is reliable. The effect size was large but it was not statistically significant.

One limitation of this study is that only articles published in English were considered. We did not consider research papers published in other languages. Another limitation is that the number of studies included is small, and this limits the interpretation of results. Despite the systematic and comprehensive search of data, only 9 studies were selected for the meta-analysis. The sample size was small; therefore, the effect size of the intervention tended to be overestimated. Further studies should consider the effects of hippotherapy on the function, gait, and balance of children with $\mathrm{CP}$ in clinical rehabilitation settings.

In this study, the effect size of hippotherapy on children with $\mathrm{CP}$ was determined using data from studies published up to September 2018. The practical application of hippotherapy and suggestion for the direction of future studies were also presented. Our results show that the effect size of hippotherapy was the highest for gait $(\mathrm{d}=-3.82)$, followed by balance, and was the lowest for function, but no statistically significant differences were observed. There is still a lack of clarity and a considerable lack of RCTs in this research area. Therefore, it is essential that many more RCTs be conducted on hippotherapy for children with $\mathrm{CP}$ in the future.

\section{Conflict of Interest}

The authors declared no potential conflicts of interest with respect to the authorship and/or publication of this article.

\section{References}

1. Shumway-Cook A, Woollacott MH. Motor control: translating research into clinical practice. 3rd ed. Philadelphia: Lippincott Williams \& Wilkins; 2007.

2. Stanley F, Blair E, Alberman E. Cerebral palsies: epidemiology and causal pathways. London: Cambridge University Press; 2000.

3. Krejci E, Janura M, Svoboda Z. The benefit of hippotherapy for improvement of attention and memory in children with cerebral palsy: a pilot study. Acta Gymnica 2015;45:27-32.

4. Pavão SL, Nunes GS, Santos AN, Rocha NA. Relationship between static postural control and the level of functional abilities in children with cerebral palsy. Braz J Phys Ther 2014;18:300-7.

5. Liptak GS. Complementary and alternative therapies for cerebral palsy. Ment Retard Dev Disabil Res Rev 2005;11:156-63.

6. Frank A, McCloskey S, Dole RL. Effect of hippotherapy on perceived self-competence and participation in a child with cerebral palsy. Pediatr Phys Ther 2011;23:301-8.

7. Ketelaar M, Vermeer A, Hart H, van Petegem-van Beek E, Helders PJ. Effects of a functional therapy program on motor abilities of children with cerebral palsy. Phys Ther 2001;81:1534-45.

8. Yeo SM, Lee JY, Shin HY, Seo YS, Kwon JY. Factors influencing motor outcome of hippotherapy in children with cerebral palsy. Neuropediatrics 2019;50:170-7.

9. Stergiou A, Tzoufi M, Ntzani E, Varvarousis D, Beris A, Ploumis A. Therapeutic effects of horseback riding interventions: a systematic review and meta-analysis. Am J Phys Med Rehabil 2017; 96:717-25.

10. Hamill D, Washington KA, White OR. The effect of hippotherapy on postural control in sitting for children with cerebral palsy. Phys Occup Ther Pediatr 2007;27:23-42.

11. Franjoine MR, Gunther JS, Taylor MJ. Pediatric balance scale: a modified version of the berg balance scale for the school-age child with mild to moderate motor impairment. Pediatr Phys Ther 2003;15:114-28.

12. Janura M, Peham C, Dvorakova T, Elfmark M. An assessment of the pressure distribution exerted by a rider on the back of a horse during hippotherapy. Hum Mov Sci 2009;28:387-93.

13. RDA-Samsung. Riding for the disabled. Gunpo: SAMSUNG Equestrian Team; 2002.

14. Zadnikar M, Kastrin A. Effects of hippotherapy and therapeutic horseback riding on postural control or balance in children with cerebral palsy: a meta-analysis. Dev Med Child Neurol 2011;53: 684-91. 
15. Martín-Valero R, Vega-Ballón J, Perez-Cabezas V. Benefits of hippotherapy in children with cerebral palsy: a narrative review. Eur J Paediatr Neurol 2018;22:1150-60.

16. Shin WJ. An introduction of the systematic review and metaanalysis. Hanyang Med Rev 2015;35:9-17.

17. Higgins JPT, Green S. Cochrane handbook for systematic reviews of interventions. Chichester: Wiley-Blackwell; 2008. p. 266-78.

18. Oh SS. Meta-analysis : theory and practice. Seoul: Konkuk University Press; 2002. p. 185-89.

19. Ando T, Takagi H, Briasoulis A, Grines CL, Afonso L. Comparison of health related quality of life in transcatheter versus surgical aortic valve replacement: a meta-analysis. Heart Lung Circ 2019;28:1235-45.

20. Egger M, Davey Smith G, Schneider M, Minder C. Bias in meta-analysis detected by a simple, graphical test. BMJ 1997; 315:629-34.

21. Park WJ, Park SJ, Hwang SD. Effects of Cognitive Behavioral Therapy on attention deficit hyperactivity disorder among schoolaged children in Korea: a meta-analysis. J Korean Acad Nurs 2015;45:169-82.

22. Champagne D, Corriveau H, Dugas C. Effect of hippotherapy on motor proficiency and function in children with cerebral palsy who walk. Phys Occup Ther Pediatr 2017;37:51-63.

23. McGibbon NH, Benda W, Duncan BR, Silkwood-Sherer D. Immediate and long-term effects of hippotherapy on symmetry of adductor muscle activity and functional ability in children with spastic cerebral palsy. Arch Phys Med Rehabil 2009;90:966-74.

24. Silkwood-Sherer DJ, Killian CB, Long TM, Martin KS. Hippotherapy--an intervention to habilitate balance deficits in children with movement disorders: a clinical trial. Phys Ther 2012;92: 707-17.

25. Mutoh T, Mutoh T, Tsubone H, Takada M, Doumura M, Ihara M, et al. Impact of serial gait analyses on long-term outcome of hippotherapy in children and adolescents with cerebral palsy. Complement Ther Clin Pract 2018;30:19-23.

26. Casady RL, Nichols-Larsen DS. The effect of hippotherapy on ten children with cerebral palsy. Pediatr Phys Ther 2004;16:16572.

27. Davis E, Davies B, Wolfe R, Raadsveld R, Heine B, Thomason $\mathrm{P}$, et al. A randomized controlled trial of the impact of therapeutic horse riding on the quality of life, health, and function of children with cerebral palsy. Dev Med Child Neurol 2009;51:111-9.

28. McGee MC, Reese NB. Immediate effects of a hippotherapy session on gait parameters in children with spastic cerebral palsy.
Pediatr Phys Ther 2009;21:212-8.

29. McGibbon NH, Andrade CK, Widener G, Cintas HL. Effect of an equine-movement therapy program on gait, energy expenditure, and motor function in children with spastic cerebral palsy: a pilot study. Dev Med Child Neurol 1998;40:754-62.

30. Kwon JY, Chang HJ, Yi SH, Lee JY, Shin HY, Kim YH. Effect of hippotherapy on gross motor function in children with cerebral palsy: a randomized controlled trial. J Altern Complement Med 2015;21:15-21.

31. Cherng RJ, Liao HF, Leung HWC, Hwang AW. The effectiveness of therapeutic horseback riding in children with spastic cerebral palsy. Adapt Phys Activ Q 2004;21:103-21.

32. Kang H, Jung J, Yu J. Effects of hippotherapy on the sitting balance of children with cerebral palsy: a randomized control trial. J Phys Ther Sci 2012;24:833-6.

33. Herrero P, Gómez-Trullén EM, Asensio A, García E, Casas R, Monserrat E, et al. Study of the therapeutic effects of a hippotherapy simulator in children with cerebral palsy: a stratified single-blind randomized controlled trial. Clin Rehabil 2012;26: 1105-13.

34. Berman NG, Parker RA. Meta-analysis: neither quick nor easy. BMC Med Res Methodol 2002;2:10.

35. Lucena-Antón D, Rosety-Rodríguez I, Moral-Munoz JA. Effects of a hippotherapy intervention on muscle spasticity in children with cerebral palsy: a randomized controlled trial. Complement Ther Clin Pract 2018;31:188-92.

36. El-Meniawy GH, Thabet NS. Modulation of back geometry in children with spasticdiplegic cerebral palsy via hippotherapy training. Egypt J Med Hum Genet 2012;13:63-71.

37. Kwon JY, Chang HJ, Lee JY, Ha Y, Lee PK, Kim YH. Effects of hippotherapy on gait parameters in children with bilateral spastic cerebral palsy. Arch Phys Med Rehabil 2011;92:774-9.

38. Park ES, Rha DW, Shin JS, Kim S, Jung S. Effects of hippotherapy on gross motor function and functional performance of children with cerebral palsy. Yonsei Med J 2014;55:1736-42.

39. Benda W, McGibbon NH, Grant KL. Improvements in muscle symmetry in children with cerebral palsy after equine-assisted therapy (hippotherapy). J Altern Complement Med 2003;9:81725.

40. Deutz U, Heussen N, Weigt-Usinger K, Leiz S, Raabe C, Polster $\mathrm{T}$, et al. Impact of hippotherapy on gross motor function and quality of life in children with bilateral cerebral palsy: a randomized open-label crossover study. Neuropediatrics 2018;49:18592. 